\title{
ARCHAEOLOGY
}

\section{WEST ANATOLIAN MINING IN EARLY BRONZE AGE (3000-2000 BC)}

\begin{abstract}
The discovery of people's mines and the use of them has been a major breakthrough in the development of civilization. In Anatolia, which has rich ore deposits, it is seen that people recognized the mines from the Neolithic Age. When the Early Bronze Age came, mining activities became very widespread. In western Anatolia, centers such as Troia, Limantepe and Beycesultan have become masters of metal production. In this article, in the Early Bronze Age, the mining of the western Anatolian region is evaluated. In this context, mineral deposits of the Western Anatolian region, mineral products and their usage areas, archaeological sites that found metal were investigated. In addition, the use of metals such as copper, tin, bronze, lead, gold, silver and iron in the region has been discussed.
\end{abstract}

Keywords: West Anatolia, Early Bronze Age, Mining, Troia, Beycesultan.

\section{INTRODUCTION}

natolia is an important region in terms of mineral resources and prehistoric mining. Determination of mineral deposits in KonyaÇatalhöyük and Aksaray-Aşıklı Mound in Anatolia from the Neolithic Age (9000 BC) shows that mines have been explored and used in Anatolia since the earliest times. This early period mining will show great improvement over time. Following the Chalcolithic Age (5000-3000 BC), the discovery of bronze, a mixture of copper and tin, gave a name to the age of the Bronze Age (Bronze Age), due to the fact that mining and mining techniques reached a very advanced stage. During the Early Bronze Age (3000-2000 BC) mining will develop very much in Anatolia. The presence of various metal objects in most of the Early Bronze Age (EBA) centers reveals the development of mining.

Mining requires specialization. For this reason, it should be thought that mining has developed independently in various forms in various centers. The ore extracted from the mine or from the galleries is turned into metal ingots in a place nearby. These metal ingots are also taken to the centers where the workshops for the mines are located. The metal ingots brought to the workshops are processed here by specialists and various tools and artifacts are made.

After the metal is extracted from the soil, it is subjected to various procedures ranging from being metalized. These steps should be as follows. The ore extracted as crude is first turned into a metal ingot. The mines which are produced are distributed by trade. The specialists produce the desired tools and artifacts through the various operations of the metal ingots. They are then traded. The passing of mines through different processes requires

\section{Harun Oy}

Ordu University

harunoy@odu.edu.tr

DOI: $10.14795 /$ j.v4i2.219

ISSN $2360-266 \mathrm{X}$

ISSN-L 2360 - 266X 
knowledge and experience that will require the expertise of various professional groups. Commercial distribution is an important branch that requires organization and control.

The mined ore is transported to various centers after being made into ingots. For this reason, mines that are formed into nut-shaped, oxhide-shaped and rod-shaped metal ingots are commercially easier to market. Nutshaped metal ingots were found in Troia II (2500-2300 BC) in Western Anatolia. Oxhide-shaped metal ingots was found in various shipwrecks dated to the Bronze Age in the Mediterranean. Rod-shaped metal ingots were discovered at various Bronze Age centers.

In the Early Bronze Age (3000-2000 BC), metals such as copper, tin, lead, as well as gold, silver and electron are used $^{1}$. In the early days, objects made from mine were used as objects of prestige, but they became widespread with the use of tools and weapons ${ }^{2}$. It is known that during the Early Bronze Age various minerals were extracted, processed and made in the form of ingots in Anatolia.

In the Early Bronze Age mass production is not seen in mining. More local production centers will develop mining through trial and error. Advanced mining activities can be seen in many different regions. There is also a great increase in the Early Bronze Age in respect of the metalwork recovered. Much of the finds are dated to the Early Bronze Age. This marks the development of the mining industry in the Early Bronze Age.

In the Early Bronze Age, mines found on the surface of the soil as well as on the bottom of the soil and in the depths have been started to be searched and extracted. It is seen that the mining has developed thanks to the mine galleries dated to this period. Along with these developments, at 4000 $\mathrm{BC}$ new mines will begin to be recognized and processed in Anatolia.

Western Anatolian mining will be shaped in the Late Chalcolithic Age (5000-3000 BC) with local characteristics and will begin to develop in the Early Bronze Age I (30002700 BC). In the Early Bronze Age II (2700-2400 BC) it will rise to the top ${ }^{3}$. Over time, stone tools will be replaced by tools made of metal. Metal finds are encountered in almost all of the settlements where archaeological excavations are performed. The presence of metal artifacts in many settlements not close to the mine beds suggests that the mines distributed in trade are being processed in these settlements ${ }^{4}$. Many mine pots and tunnels discovered in excavations support this. In very rare works with very fine workmanship, it goes to the remote regions as a prestige object.

Early Bronze Age II (2700-2400 BC) is a period of time when the metal industry developed, the methods of metal processing were diversified, the raw materials and metal trade were organized and concentrated and new techniques were used. In addition, various mines are being mixed and used in this period. The mines extracted from the quarries are transformed into ingots and delivered to the distant point of trade. Mining has become organized in the process

WAGNER et alii 1984; KAPTAN 1995b, 190; KAPTAN 2006, 467; JONES 2007, 110; YALÇIN 2009, 99.

2 ŞAHOĞLU 2005, 341; JONES 2007, 110.

YALÇIN 2003, 533; FIDAN 2006, 95; YALÇIN 2009, 99.

BİLGì 1997, 7. of producing the ore extracted from the galleries until the production in the manufacturing 5 .

From the Early Bronze Age II, there is an increase in the number of metal works. It is used in casting in closed molds besides open molds ${ }^{6}$. Due to the increase in metal usage, the production and trade of obsidian and chipped stone tools will begin to decrease from Early Bronze Age II ${ }^{7}$.

The mining activities that existed in the Chalcolithic Age continued in the Early Bronze Age in a much more diverse, organized way. For this reason, Anatolia is an important center for the development of early metallurgy ${ }^{8}$. In Early Bronze Age II, mining technology has shown great improvement ${ }^{9}$. Early examples of mining are found in Anatolia, making Anatolia an important center for mining ${ }^{10}$.

\section{WESTERN ANATOLIA MINERAL DEPOSITS}

Anatolia has rich gold, silver, copper, lead, zinc and iron mines. These mines are concentrated in the south of the Black Sea ${ }^{11}$, in the Taurus Mountains ${ }^{12}$ and in the Troas Region in Western Anatolia ${ }^{13}$. The Taurus Mountains are especially important for mining activities in Early Bronze Age II and III ${ }^{14}$. Strabo from the Antiquity writers; Hermos and the Pactolos River through Sardis and Astyra in Troas speak of the wealth of gold ${ }^{15}$. These rich mineral deposits in Western Anatolia have always attracted people's attention.

These rich deposits in Western Anatolia can be summarized as follows; Gold in Kirazlı district of Çanakkale Province, copper in Lapseki, gold in Kartalkaya in the south of Çanakkale Province, and silver mines in Üsküfçü ${ }^{16}$. Gold in the province of Salihli of Manisa, Arapdağı Mevkii of Karşıyaka District of Izmir, Bergama, Tire and Ödemiş ${ }^{17}$. Balıkesir has rich silver and lead deposits in the Balya District $^{18}$. There are lead mines in Balikesir, Çanakkale, İzmir-Gümüldür ${ }^{19}$ and Edremit. Gold deposits especially in Western Anatolia. The rich gold mines of Western Anatolia were operated in the Early Bronze Age ${ }^{20}$.

There are rich silver mines in İzmir, Uşak, Güre and Kütahya ${ }^{21}$. The $C 14$ analyzes on the slags in the mineral deposits in Kütahya Gümüşköy indicate today 4000 years ago. It is evident that this mine in Kütahya-Gümüşköy was

\footnotetext{
BİLGİ 1997, 5; BİLGİ/ÖZBAL/YALÇIN 2004, 14; YALÇIN 2008, 15-20.

BİLGİ/ÖZBAL/YALÇIN 2004, 17.

KOLANKAYA BOSTANCI 2008, 175

YENER 2000, 17

SAHOĞLU 2005, 341; DE RYCK/ADRİAENS/ADAMS 2005, 266.

MÜLER KARPE 1994, 184.

MUHLY/WERTIME 1973, 111; KAPTAN 1980, 65-71; KASSİANIDOU/

KNAPP 2005, 215.

12 YENER et alii 1991, 541-570.

3 WAGNER et alii 1984, 48, Abb. 1; STOS GALE/MACDONALD 1991, 276 280; STOS GALE/GALE 1990, 92; KASSİANIDOU/KNAPP 2005, 219, Fig. 9,

1; GALE 2008, 221, Fig. 9.

4 ŞAHOĞLU 2005, 341

5 STRABO, GEOGRAPHİCA 13, 4-5.

WAGNER et alii 1984; KORFMANN 2003b, 7; PERNICKA/EIBNER/ ÖZTUNALI/WAGNER 2003, 150.

SOYKAN/MUTLUER 1995, 47; ŞENER 2003, 519; LENGERANLI 2008 , 355; AKISKA/ÜNLÜ/SAYILI 2008.

18 KOVENKO 1940, 587-593; DE JESUS 1978, 97-102; DE JESUS 1980, 65; WAGNER et alii 1984.

19 PERNICKA/EİBNER/ÖZTUNALI/WAGNER 2003, 150-157.

20 YOUNG 1972, 13.

PERNİCKA/EİBNER/ÖZTUNALI/WAGNER 2003, 156; BİLGİ/ÖZBAL/
}

YALÇIN 2004, 34; KARTALKANAT 2008, 93. 


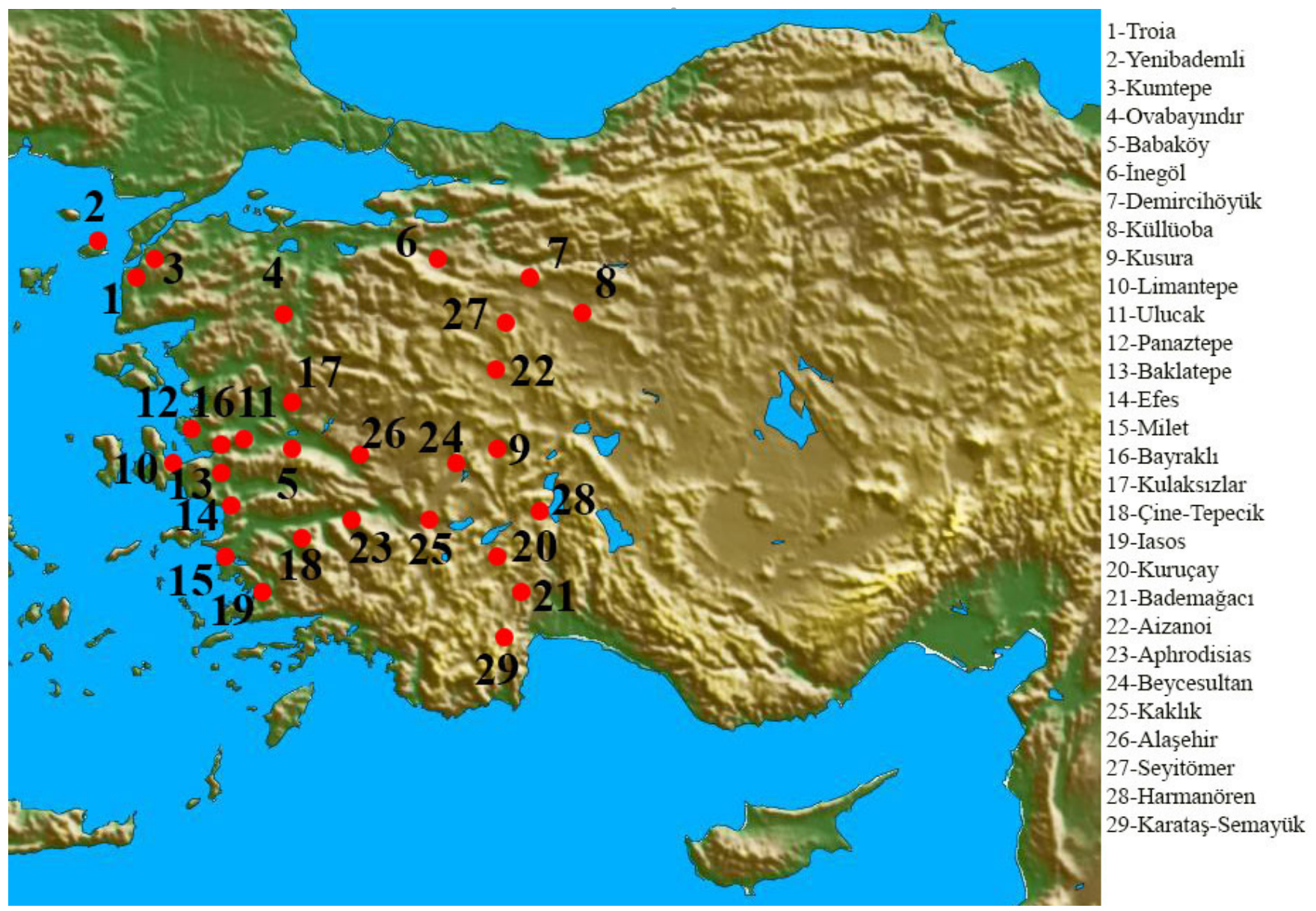

Fig. 1. Map, Western Anatolia Early Bronze Age settlements.

used in 3000-2000 BC, and various underground galleries are dated to this period ${ }^{22}$.

The closest copper, lead, zinc deposits and formations to İzmir-Limantepe, which is located on the shore other than Troia in Western Anatolia, are Buca-Maden Tepe, KemalpaşaYeni Kurudere and Ovacık Yayla, Bayindir-Sarıyurt-Ilıcadere, Menderes- Efem Çukuru, Gümüldür-Gümüşsu is thought to be. These formations and deposits do not currently represent economic value. However, it can be considered that these deposits, which are close to Limantepe, were used in the Late Chalcolithic Age (3500-3000 BC) and the Early Bronze Age (3000-2000 BC). The closest mining site to İzmir-Baklatepe is Sandiköy. This mine contains lead, zinc, copper, manganese, gold deposits. Although it is not economically important today, this area should have been used by Baklatepe miners in the early period. It is inevitable that at least some of these rich mineral deposits in Western Anatolia have attracted the attention of Early Bronze Age people.

\section{MINING PRODUCTS AND USAGE AREAS}

Despite the fact that the mineral products and fields of use are a very wide subject, the artefacts discovered in the archaeological excavations are composed of jewelery, ornaments, various tools and works. For this reason, we give definite mines products and usage areas here (Fig. 1).

Early Bronze Age is a time when mining has developed and new techniques have been used in mining.

\footnotetext{
22 KAPTAN 1982, 59-67; KAPTAN 1990, 77-78; KAPTAN 1995b, 191.
}

In many centers in western Anatolia, as well as obtaining metal artifacts, blowers, metal melting and casting pots and pestles were found. Various metal molds are used in casting of metals. When casting, three-way mine molds were used besides single and double faced mine molds. These molds are made of flat and armored axes, knives, daggers, chisels, tools and weapons, figurines and various items. In wax molds, Troia II (2500-2300 BC) was also used for casting lead figurines and ornamental needles.

Copper ingots are found in Anatolia, Çorum-Boğazköy, Antalya coasts, Gelidonya and Uluburun wrecks, TekirdağŞarköy. Copper ingots were also found in the Aegean Islands and Greece, in the Sicilian coasts, and in the western coasts of the Black Sea ${ }^{23}$. Oxhide-shaped ingots found in many places in the Mediterranean are cast in a certain standard and shape with an average weight of $25-29 \mathrm{~kg}$, which is easy to carry ${ }^{24}$. This is important in that it demonstrates that mining production and operations are very systematic and standardized.

Because the metals are valuable, they have been used by melting again. For this reason, we could find information about early-period mining in small quantities. We obtain most of these limited mine finds from wrecks in the seas and grave gifts. Most of the metal works in the museums consist of the finds recovered from the graves. The vast majority of these finds consist of jewelery and ornamental items. It is

\footnotetext{
23 WHEELER/MADDIN/MUHLY 1975; JONES 2007, 420-430. ${ }^{24}$ WHEELER/MADDİN/MUHLY 1975; JONES 2007, 420-430.
} 
also seen in tombs in instruments, weapons, various vessels and symbolic goods.

Ornamental needles occupy an important place in metal finds. Bronze, copper, iron, silver, gold, electron ornaments made of metals such as the needles, as well as examples of bone, glass and wood can be seen. Ornamental needles have existed since the Late Chalcolithic. But it is intensively seen in the Early Bronze Age.

Troia is the most important center for mining in Western Anatolia and the Aegean during the Early Bronze Age $^{25}$. The example of the mine found in the Troia I (BC 2900-2500) layers indicates the mining activities there ${ }^{26}$. In Beşik-Sivritepe, which is close to Troia, there are tools made of mineral materials. The metal axes recovered here are important for showing the mining activities in the region. In Gökçeada-Yenibademli Höyük located in Troas region, stone hammer, crushing stones, pots, molds and blowers related to mining were discovered. Minor finds such as knives, pins, buckles, tweezers and arrows indicate mining activities there ${ }^{27}$.

It is important to show mining activities such as mine molds, blowers, copper slags, pots, mine preparation, crushing and breaking tools which are unearthed in İzmirLimantepe Late Chalcolithic Age and Early Bronze Age I-III floors on the western Anatolian coast ${ }^{28}$. In the Early Bronze Age architectural layers of İzmir-Baklatepe, copper, gold, silver materials and finds belonging to mining production such as copper slags, blowers, pots made from cooked soil emerged. Late Chalcolithic and Early Bronze Age I copper slags and pot remains indicate the presence of these mining activities $^{29}$.

The metal tools, axes and pins found in EskişehirKüllüoba indicate the existence of mining activities here. In Küllüoba there is a large increase in the number of tools made of ornamental needles and mines in Early Bronze Age $\mathrm{II}^{30}$. Demircihöyük Early Bronze Age I-II belongs to various jewelery and ornaments, cutters and tools and some works were found. It is important to show that mining is done in Demircihöyük, which is a metal mold of copper lead alloy casting mold piece and tin traces ${ }^{31}$.

Antalya-Bademağaci'da various jewelry, ornaments, weapons and tools, gold ear plugs are available ${ }^{32}$. In addition to gold works, there are arsenic copper production items in the majority. These works shed light on Bademağacı's mineral products and uses in the Early Bronze Age. Kuruçay Höyük has advanced mining in the Late Chalcolithic Age. Many of the metal casting found in the settlement show this.

A large number of wedges were found in the tombs of Balikesir-Ovabayındır. These wedges are similar in Northwest Anatolia, Central Anatolia and the Aegean. In Isparta-Harmanören, various ornamental needles, rings and bracelets, earrings and rings, metal objects and amulet were

\footnotetext{
DAYTON 1971, 59; DE JESUS 1980, 136; YAKAR 1985, 389; TREISTER 1996; LAFFINEUR 2008, 328.

26 MÜLER KARPE 1994, 43.

27 HÜRYILMAZ 2008, 148

28 ERKANAL 2008b, 180

29 ERKANAL 2008a, 165.

30 EFE/AY EFE 2001, 51; EFE/FİDAN 2006, 15-43.

31 SEEHER/KAUDER 1996, 313-314.

32 DURU 1995, 72.
}

found $^{33}$. In Afyonkarahisar-Kusura Höyük there are various metal needles, bices and axes ${ }^{34}$. In Denizli-Karahisar, bronze pins, bracelets and a melting pot were seized ${ }^{35}$. The metal artifacts found in the western Anatolia and its surrounding and excavated centers are important for revealing the richness of mining in the region.

\subsection{COPPER USAGE}

Copper is a soft, easy to process metal. Copper, the first mine that man first met, was used in Anatolia from the Neolithic Age (9000 BC Diyarbakır-Çayönü and AksarayAşıklı Höyük). At first, the copper obtained by collecting from the soil surface was started to be obtained from the ores later $(5000 \mathrm{BC})^{36}$. In the Chalcolithic Age, arsenic copper production started first and then tinned copper production was started. Arsenic copper is common in most places. The use of copper in the Aegean increases in the Early Bronze Age $\mathrm{I}^{37}$. The copper that Greece needs is probably from Anatolia and the Balkans. During the Early Bronze Age II, mining became more widespread and demand for mining increased. From 2000 BC the use of tinned bronze will increase ${ }^{38}$.

There are copper mines in Crete and Cyclades, especially in Cyprus, in the Aegean ${ }^{39}$. Many settlements in Cyprus have finds pointing to the Early Bronze Age mining ${ }^{40}$. While the use of tinned copper in Troia is widespread, the use of arsenic copper in the Aegean islands is widespread. This shows that Troia is getting tinned ${ }^{41}$. In the Early Bronze Age II in Troia, the analysis of at least two different roots belonging to copper was concluded ${ }^{42}$. The production of tinned bronze must have passed from the Western Anatolia to the Aegean islands ${ }^{43}$. Some examples of lead isotope analysis in the Aegean Islands show that some of them are of Anatolian origin ${ }^{44}$.

It is thought that arsenic copper technology emerged in Anatolia and spread rapidly in $4000 \mathrm{BC}$ to the west of the Black Sea, to the Balkans and Central Europe ${ }^{45}$. Besiktepe metal finds are related to Troia I finds ${ }^{46}$. Similar to the birdheaded copper needle found at Beşik-Yassitepe, it is seen in Thermi ${ }^{47}$. Kumtepe Ib-c layers copper pins, daggers and wedges were found. This is important in that it points to links with other centers in Troia's territory.

The mining slags recovered in Altintepe, near Menderes District in the south of Izmir, are an important place showing the Chalcolithic and Early Bronze Age copper

\footnotetext{
3 ÖZSAİT 2000, 372.

34 LAMB 1937, 64; DE JESUS 1980, 132; YAKAR 1985, 384.

YAYLALI/AKDENIZ 2002, 27-28, 31.

CAMBEL/BRAİDWOOD 1970, 50-56; DE JESUS 1972, 130; MUHLY 1988, 5-7; MÜLER KARPE 1994, 183; PİGOTT 1999, 3; CİERNY/ WEİSBERGER 2003, 23; BİLGİ/ÖZBAL/YALÇIN 2004, 5; YALÇIN 2009, 99. 37 JONES 2007, 253-255; STOS GALE/GALE 1990.

38 DE JESUS 1978, 97-102; SHEPHERED 1993, 219-222; KAPTAN $1995 \mathrm{a}, 197$.

39 BEAR 1963; BRANIGAN 1974, 59-60; WHEELER/MADDİN/MUHLY 1975,32 .

40 STOS GALE/GALE 1990; JONES 2007, 253-255;

${ }^{41}$ BRANİGAN 1974, 74; EATON/MCKERRELL 1976, 170.

42 GALE/STOS GALE/GILMORE 1985, 147.

3 WRİGHT 1998, 366.

4 GALE/STOS GALE 2004.

45 BEGEMANN/PERNICKA/SCHMITT STRECKER 1994; MUHLY 1999,

16; YENER 2000; NIKKOLOVA 2005, 89, Fig. 1; NİKOLOVA 2008, 164.

46 BEGEMANN/SCHMİTT STRECKER/PERNICKA 2003, 173-200.

47 KORFMANN 1986, 264.
} 
mining. This is an important center for processing raw mine in Western Anatolia ${ }^{48}$. A large number of copper slags were discovered between the Late Chalcolithic Age (7th layer) and Early Bronze Age II (5th Layer) of İzmir-Limantepe ${ }^{49}$. In the Early Bronze Age architectural layers of İzmir-Baklatepe, finds belonging to mining production such as copper, copper slags, blowers and pots came out. Late Chalcolithic Age and Early Bronze Age I copper slags and pot remains indicate the presence of these mining activities ${ }^{50}$.

Eskişehir-Demircihöyük various jewelery and ornaments belonging to the Early Bronze Age I-II, cutters and tools, arsenic copper and tin bronze artifacts were found. The part of the copper lead alloy casting mold indicates the casting activities there ${ }^{51}$. Among the various finds found in the Demircihöyük-Sarıket graveyard are metal finds consisting of various tools, jewelery and ornaments, 156 copper or bronze, and 4 arsenic copper. This number indicates that copper and its alloys are heavily used ${ }^{52}$. In Eskişehir-Küçükhöyük Early Bronze Age II grave, various jewelery and ornaments made from copper were found ${ }^{53}$.

The metal artifacts found in the Balikesir-Yortan graveyard were all made of arsenic copper. Only one piece was identified as tinned bronze ${ }^{54}$. The works of BursaIlpinar Late Chalcolithic Age are made of arsenic copper. At Barçın Höyük, a copper or copper alloy ax dating to the Late Chalcolithic Age was found in the M11 area ${ }^{55}$.

Denizli-Beycesultan has developed metallurgy since the Chalcolithic period. Copper finds here are important for the metallurgy of Western Anatolia ${ }^{56}$. In AfyonkarahisarKusura Höyük, artefacts such as various needles, wisps and axes contain arsenic copper ${ }^{57}$.

Antalya-Bademağacı'da various jewelry, ornaments, weapons and tools were found ${ }^{58}$. In addition to gold works, there are also arsenic copper production items in the majority. In Antalya-Karatas-Semayük, most of the metal works belonging to Early Bronze Age II are copper or bronze, and very few arsenic copper. Among these finds, the use of copper and its alloys in addition to the use of other metals in the Karataş community is more widespread ${ }^{59}$. Arsenic copper and tinned copper are widely used in Western Anatolia.

\subsection{TIN USAGE}

It's a question of where the tin is supplied ${ }^{60}$. In the Early Bronze Age, it was unclear from where the tin was obtained, and it was acquired by traders from Mesopotamia in 2000 BC for trading from the sides of Afghanistan ${ }^{61}$. Branigan notes that Troia II (2500-2300 BC) is very

${ }_{48}$ BOSTANCI 2006, 165.

49 KAPTAN 2008, 245-246.

50 ERKANAL 2008a, 165-173.

51 SEEHER/KAUDER 1996, 313-314.

52 SEEHER 2000, 230.

53 GÜRKAN/SEEHER 1991, 85-93. Abb. 22-26.

54 AKDENIZ 2009, 51.

55 GERRİTSEN/ÖZBAL 2009, 457, Fig. 3.

56 STRONACH 1959, 48; LLOYD/MELLAART 1962, 280; DE JESUS 1980, 129; YAKAR 1984, 64, 74; YAKAR 1985, 389; BİLGİ/ÖZBAL/YALÇIN 2004, 14.

57 LAMB 1937, 64; DE JESUS 1980, 132; YAKAR 1985, 384.

58 DURU 1995, 72.

59 WARNER 1994, 207.

60 MUHLY/WERTIME 1973, 122; KAPTAN 1981, 106; MUHLY 1985, MUHLY 1993.

61 KAPTAN 1990, 76; KLENGEL 2009, 175. flourishing and that tin and bronze are obtained through trade $^{62}$. In Troia II, the tinned tin ratio is $10 \%$, which is ideal. In Crete this rate is only $5 \%$. In this case, it can be seen that Troia easily obtained the $\operatorname{tin}^{63}$. Dayton states that tin is imported from Hungary or Spain. Rich cities such as Troia and Poliochni can commercially obtain $\operatorname{tin}^{64}$. But this has not been proven. Lapislazuli and amber were found in Troia. Lapislazuli came from Afghanistan, amber from the Baltic Sea. It is possible that Troia, which has commercial relations at such a long distance, can also commercially obtain $\operatorname{tin}^{65}$. Though stones such as lapislazuli and agate came from the Afghanistan region, it is thought that tin could come from Iran, Afghanistan and Central Asia ${ }^{66}$.

The presence of various tools belonging to the Eskişehir-Demircihöyük Early Bronze Age I-II period in Western Anatolia as well as the presence of a mine base from the basement with tin traces is important as it shows that tin is processed in Demircihöyük ${ }^{67}$.

Tinned copper production is spreading to northern Mesopotamia, Central Anatolia and Western Anatolia to Troia. In other regions arsenic copper production continued. In Anatolia, the use of arsenic copper in Troia, Yortan, Kusura, Alisar, Alacahöyük, Mahmatlar, Horoztepe, Gözlükule and Yumuktepe as well as the use of tinned copper is observed. However, the use of arsenic copper continues in settlements such as Samsun-Ikiztepe and Malatya-Aslantepe. Since the earliest examples are seen in Anatolia, it is probable that tin Anatolia was produced ${ }^{68}$. According to another opinion, there are some tin in alluvial sand. It is thought that tin may have been obtained from these sand ${ }^{69}$.

Though tin minerals are found in Anatolia, their economic dimension is not sufficient. For 5,000 years, tin has been used as an alloying material in Anatolia. Bursa, Soğukpınar, Madenbelenitepe, Kırklareli Saray and Burgaz districts in Western Anatolia, a tin deposit was found near Eskisehir. But they are not economically adequate and qualified $^{70}$. It is known that tin stones occur in Western Anatolia, in Darmanlar in the southern part of İzmir, in Murat Mountain near Uşak and in Bilecik, Mihalgazi ${ }^{71}$ and Sakarya valleys.

It is thought that the tin needed in the Early Bronze Age was obtained from small deposits in Anatolia. Yener states that the Niğde Kestel mine has been used in this date and that its need is provided here ${ }^{72}$. This situation has not been accepted by many scientists ${ }^{73}$. Lately, in KayseriHisarcik, tin deposits have been discovered and new tin deposits will be discovered in Anatolia with the progress of the investigations ${ }^{74}$.

The only tin source of Western Anatolia was found

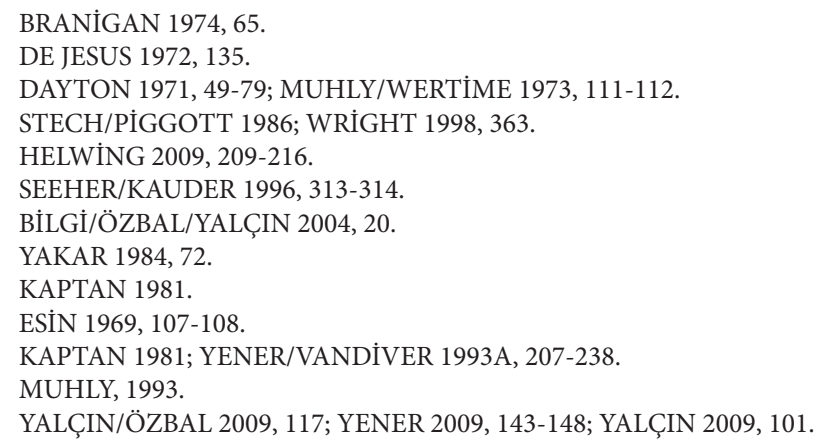


in Bursa Kestel (Madenbelenitepe) ${ }^{75}$. But it has not been proven to be used in prehistoric times ${ }^{76}$.

In Central Anatolia Niğde, Ulukışla Bolkar Mountains were found tin presence ${ }^{77}$. The tin mines in Niğde Celaller were operated from the Early Bronze Age (3000 BC) to the Byzantine period $^{78}$. During this time it is estimated that 1000 tons of tin production has been carried out here. It is thought that 1,7 tons of tin production has been carried out in the 600 years of the year and that it fulfills $3 / 1$ of the needs of the region. The old mine in Niğde Celaller has found mining workshops, mine melting pots and mortars used for grinding mines ${ }^{79}$. Göltepe is dated to between 4350-1978 BC. It has been documented that tin production has been made in the analysis carried out on a large number of metal slag, pots and vessels recovered here ${ }^{80}$.

Small tin mines in Kestel (3623-2147 BC) in Niğde and Göltepe (4350-1978 BC) were used and consumed in the Early Bronze Age ${ }^{81}$. Since the tin need was not met from Anatolia in 2000 BC, tin was supplied from outside.

The tin deposits that exist in the Taurus Mountains have been consumed extensively in the Early Bronze Age. For this reason, Assyrian traders brought tin out of Anatolia in 2000 BC. The activities of Assyrian merchants are beginning to gain intensity in this period ${ }^{82}$. Tin is distributed not only in Anatolia but also in the Mediterranean and the Aegean, as it is a mineral required by other regions ${ }^{83}$.

\subsection{BRONZE USAGE}

Besides the copper mine, the production of bronze, which is a mixture of copper tin, followed by the production of arsenic bronze and different alloys, shows the specialization in mining ${ }^{84}$. The earliest examples of tinned bronze in Western Anatolia were discovered in Troia I and Beşiktepe ${ }^{85}$. Early Bronze Age II shows an increase in the use of tinned bronze. Troia should have made its distribution to tinned Aegean islands in Early Bronze Age II (2500-2300 BC). In the Early Bronze Age III this situation is suddenly interrupted. The reason for this is that the tin was supplied by Assyrian merchants from Mesopotamia in $2000 \mathrm{BC}^{86}$.

It is seen that settlements giving rich metal finds for Early Bronze Age in İzmir region ${ }^{87}$. Important information

\footnotetext{
75 ÇAĞATAY/ALTUN/ARMAN 1979, 25-34; KAPTAN 1981; ÖZTÜRK/ HANILÇİ 2009, 105.

76 WAGNER et alii 1984, 45.

77 KAPTAN 1990; YENER 2009, 105.

78 WİLLIES 1990, 91-96; WİLLIES 1992B, 241-246; WİLLİES 1995, 1-10; ÖZTÜRK/HANILÇİ 2009, 105.

9 YENER/ÖZBAL/KAPTAN/PEHLIVAN/GOODWAY 1989; WİLLIES 1995; EARL/H. ÖZBAL 1996, 303; LAUGHLIN/TODD 2000, 269-270; LEHNER/YENER/BURTON 2009, 165-174; ÖZBAL 2009, 155-158.

80 YENER/VANDIVER 1993A; ADRİAENS/YENER/ADAMS 1999, 1069 1073; DE RYCK/ADRİAENS/ADAMS 2005, 266; YENER 2008, 57-58.

81 YENER et alii 1989; WİLLİES 1992A, 102; YENER/GOODWAY 1992, 85; YENER/VANDİVER 1993A, 214; YENER/VANDİVER 1993B, 261-262; YENER 2000, 70-73; YENER/ANDRİAENS/EARL/ÖZBAL 2003, 185-187; KAPTAN 2006, 468.

82 KLENGEL 2009, 175.

83 KAPTAN 1981; YENER/VANDİVER 1993A, 221-222; YENER/VANDİVER 1993B, 261; BİLGİ/ÖZBAL/YALÇIN 2004, 20-21; PULAK 2009, 189.

84 MUHLY/PERNICKA 1992; TREISTER 1996, 229-234.

85 DE JESUS 1980, 134-137; STOS GALE/GALE 1990; MUHLY-PERNİCKA 1992: 311; GALE 2008, 209.

86 GİLLIS 1991, 12-14.

87 GENÇER 2006, 373-376.
}

about copper mining in İzmir-Baklatepe has been reached. The earliest examples of tin bronze were found in Baklatepe ${ }^{88}$. In Baklatepe, gold, silver, bronze artifacts, knives, daggers, headed needles, bracelets, rings and other mineral finds indicate a rich tradition of mining ${ }^{89}$.

In Eskisehir-Demircihöyük Early Bronze Age I-II, various jewelery and ornaments, cutters and tools, tin bronze artifacts were found ${ }^{90}$. In the Demircihöyük-Sarıket graveyard, ten of the axes, ax heads and other metal finds were made of bronze ${ }^{91}$. In Eskişehir-Küçükhöyük Early Bronze Age II cemetery, various jewelery and ornaments and tools and utensils were found. Some of these works are made of bronze ${ }^{92}$.

Bronze bracelets and needles belonging to the Early Bronze Age were found in the excavations of ManisaAlasehir $^{93}$. A large number of wedges were found in BalikesirOvabayunlu graves. These wedges are similar in Northwest Anatolia, Central Anatolia and the Aegean. Two flat bronze axes were also found. Most of the metal works belonging to Early Bronze Age II in Antalya-Karataş-Semayük are copper or bronze ${ }^{94}$. In addition to these centers, bronze finds in the metal finds in other centers in Western Anatolia are higher than other metals.

\subsection{LEAD USAGE}

Lead has been a mine used since early times for melting at very low temperatures. The earliest examples of lead beads are Çatalhöyük IX. (Neolithic) ${ }^{95}$. A lead figure dated to Troia IIg (EBA) is a fine example of the use of this mine in the Early Bronze Age in Western Anatolia ${ }^{96}$. The oldest lead mine ingot was found at Kestel-Göltepe in Niğde ${ }^{97}$. The presence of figurines, ornaments, spindles, weights, seals and various vessels made from lead in the Early Bronze Age indicates that the use of this mine is increasing. A lead ingot dating to 2000 BC was found in İzmir-Panaztepe in Western Anatolia. In Western Anatolia, the molds of the figures from the lead were found in İzmir, Troia and Küllüoba ${ }^{98}$.

Eskişehir-Demircihöyük Early Bronze Age I-II belonging to various jewelery and ornaments, cutters and tools were found. It is important to show the use of lead in Demircihöyük, which is a metal mold of copper lead alloy casting mold and tin traces in Eskişehir-Demircihöyük ${ }^{99}$. Among the 238 pieces of metal works in DemircihöyükSarıket graveyard, 35 works of lead are remarkable. Lead finds are a little more than gold finds ${ }^{100}$.

The metal tools, axes and pins found in EskişehirKüllüoba indicate mining activities in settlement. In Eskişehir-Küllüoba, a large increase is observed in the

\footnotetext{
88 ŞAHOĞLU 2005, 347.

89 ERKANAL 2008a, 165-175.

90 SEEHER/KAUDER 1996, 313-314

1 SEEHER 2000, 230

92 GÜRKAN/SEEHER 1991, 85-93. Abb. 22-26

3 MERICC 1993, 366.

4 WARNER 1994, 207.

MELLAART 1964, 97; HAMILTON 1996, 246-248; MÜLER KARPE 1994

12; YENER 2000, 24; BİLGİ/ÖZBAL/YALÇIN 2004, 9.

96 EMRE 1971, 18.

97 YENER 1995, 179.

98 EFE 2006, 301.

99 SEEHER/KAUDER 1996, 313-314.

100 SEEHER 2000, 230.
} 
number of tools made of ornamental needles and mines in the Early Bronze Age $\mathrm{II}^{101}$. In Küllüoba, a lead figurine dating to Early Bronze Age III was found ${ }^{102}$. In EskişehirKüçükhöyük Early Bronze Age II cemetery, various jewelery and ornamental items and tools were found. Three of them were made from lead ${ }^{103}$. In Afyonkarahisar-Kusura Höyük, it has been determined that various objects such as needles, wedges and axes contain lead ${ }^{104}$.

\subsection{GOLD USAGE}

Gold in the Kirazlı county of Çanakkale in Western Anatolia, and gold in Kartalkaya in the south of Çanakkale ${ }^{105}$. There are gold mines in Salihli District of Manisa, Arapdağ Mevkii, Karşıyaka District of İzmir, Bergama, Tire and Ödemiş ${ }^{106}$. Especially gold deposits are widespread in Western Anatolia. The rich gold mines of Western Anatolia were used in the Early Bronze Age ${ }^{107}$.

The various gold jewelery, artifacts and vessels in the treasure finds dated to Troia II (2500-2300 BC) are important for showing the point where Troia came socioeconomically ${ }^{108}$. Besiktepe metal finds are related to Troia I finds ${ }^{109}$. The earring made of gold from the Early Bronze Age I period of settlement is important in that it shows gold processing ${ }^{110}$.

A golden band was found at the base of a house in İzmir-Limantepe. This band dating to Early Bronze Age I is the earliest example of East Aegean and Western Anatolia. This is an important socioeconomic example of the development of Limantepe ${ }^{111}$. In the Early Bronze Age architectural layers of İzmir-Baklatepe, gold and jewelery made of gold indicate the presence of mining activities there ${ }^{112}$.

In the 1993 excavations of Manisa-Alaşehir, a golden necklace consisting of 89 pieces, 2 gold rings, 2 gold ear plugs, and a rich and crafted gold necklace belonging to a girl's Early Bronze Age grave are important for showing the art and craftsmanship of metal ${ }^{113}$.

Golden bracelets were found in the EskişehirKüçükhöyük Early Bronze Age II graveyard ${ }^{114}$. In the Demircihöyük-Sarıket graveyard, 238 pieces belonging to Early Bronze Age, which consist of a wide variety of tools, jewelery and ornaments, beak rim test, bowl, earplugs, moon axes, knob heads, bracelets and tapes and other metal finds, were found. 31 of these works are gold ${ }^{115}$.

Of the metal works belonging to Early Bronze Age II in Antalya-Karatas-Semayük, 23 of them are made of gold ${ }^{116}$.

101 EFE/AY EFE 2001, 51; EFE/FIDAN 2006, 15-43.

102 EFE 2006, 303.

103 GÜRKAN/SEEHER 1991, 85-93. Abb. 22-26.

104 LAMB 1937, 64; DE JESUS 1980, 132; YAKAR 1985, 384.

105 WAGNER et alii 1984; KORFMANN 2003b, 7; PERNICKA/EIBBNER/ ÖZTUNALI/WAGNER 2003, 150

106 SOYKAN/MUTLUER 1995, 47; ŞENER 2003, 519; LENGERANLI 2008, 355; AKISKA/ÜNLÜ/SAYILI 2008.

107 YOUNG 1972, 13.

108 MADDİN/WHEELER/MUHLY 1977, 42; WAGNER et alii 1984; TREISTER 1996, 230-234; KORFMANN 1997, 24; KORFMANN 2003a, 2527; SAZCI/TREISTTER 2006, 209-216; APAKIDZE 2008, 124.

109 BEGEMANN/SCHMITT STRECKER/PERNICKA 2003, 173-200.

110 KORFMANN 1986, 264

111 ERKANAL/ARTZY/KOUKA 2003, 425.

112 ERKANAL 2008a, 165-175.

113 MERIÇ 1993, 366.

114 GÜRKAN/SEEHER 1991, 85-93. Abb. 22-26.

115 SEEHER 2000, 230.

116 WARNER 1994.
Various jewelery, ornaments, weapons, tools, gold earplugs and other gold finds in Antalya-Bademağacı excavations draw attention. Golden ear plugs were mostly found in Western Anatolia and Central Anatolia as Alacahöyük, Karayavşan, Koçumbeli, Alisar, Karataş-Semayük, Eski Balıkhane, Ovabayindir and Yortan, mostly as grave finds ${ }^{117}$.

\subsection{SILVER USAGE}

There are rich silver mines in İzmir, Uşak, Güre and Kütahya $^{118}$. The $C 14$ analyzes on the slags in the mineral deposits in Kütahya Gümüşköy indicate today 4000 years ago. It was determined that this mine was used in 30002000 BC and that various underground galleries belong to the same period ${ }^{119}$.

Troia II (2500-2300 BC) works of silver and other precious metals indicate that Troia is an important center for mining and artifacts ${ }^{120}$. In the Early Bronze Age architectural layers of İzmir-Baklatepe, various materials made from silver were found ${ }^{121}$.

Denizli-Beycesultan, one of the important centers in Western Anatolia, has developed metallurgy since the Chalcolithic period. The various silver works found here are important for Western Anatolian metallurgy. In addition, the earliest silver finds of Western Anatolia were unearthed in Beycesultan ${ }^{122}$.

In Eskişehir-Küçükhöyük Early Bronze Age II cemetery, various jewelery and ornamental items and tools were found. Among these works are bracelets made of silver $^{123}$. Of the metal finds found in the Sarkket Cemetery, 15 are silver $^{124}$. In the Antalya-Karataş-Semayük metal works belonging to Early Bronze Age II, there are many silver finds ${ }^{125}$.

\subsection{IRON USAGE}

There are iron deposits in Çanakkale, Balıkesir and Aydın, Muğla and İzmir in Western Anatolia ${ }^{126}$.

Iron is a mine produced in $3000 \mathrm{BC}$. The use in the Early Bronze Age is not common, as high heat is needed for iron production. The widespread use of iron and its technological development has been in the Iron Age (1000 $\mathrm{BC})^{127}$. In Çorum-Alacahöyük, there were items made of iron mine dating to the Early Bronze Age (3000 BC). When the iron cools down, its process is a difficult mine, so this early example is important in that it consciously processes the iron ore and shows the point reached in mining ${ }^{128}$. Analyzes made on a scepter head belonging to Troia II (2500-2300 BC)

117 DURU 1972, 133.

118 PERNICKA/EİBNER/ÖZTUNALI/WAGNER 2003, 156; BİLGİ/ÖZBAL/ YALÇIN 2004, 34; KARTALKANAT 2008, 93.

119 KAPTAN 1982, 59-66; KAPTAN 1990, 77-78; KAPTAN 1995b, 191.

${ }_{120}$ MADDIN/WHEELER/MUHLY 1977, 42; WAGNER et alii 1984; TREISTER 1996, 230-234; KORFMANN 1997, 24; KORFMANN 2003a, 2527; SAZCI/TREISTER 2006, 209-216; APAKIDZE 2008, 124.

121 ERKANAL 2008a.

122 STRONACH 1959, 48; LLOYD/MELLAART 1962, 280; DE JESUS 1980, 129; YAKAR 1984, 64, 74; YAKAR 1985, 389; BİLGİ/ÖZBAL/YALÇIN 2004, 14; DE JESUS/DARDENIZ 2015, 240.

${ }_{123}$ GÜRKAN/SEEHER 1991, 85-93. Abb. 22-26.

124 SEEHER 2000, 230.

125 WARNER 1994, 207

126 MUHLY/MADDIN/STECH/ÖZGEN 1985, 74-77.

127 KAPTAN 1990, 76.

${ }_{128}$ PİGOTT 1982, 22; MUHLY/MADDİN/STECH/ÖZGEN 1985, 71. 


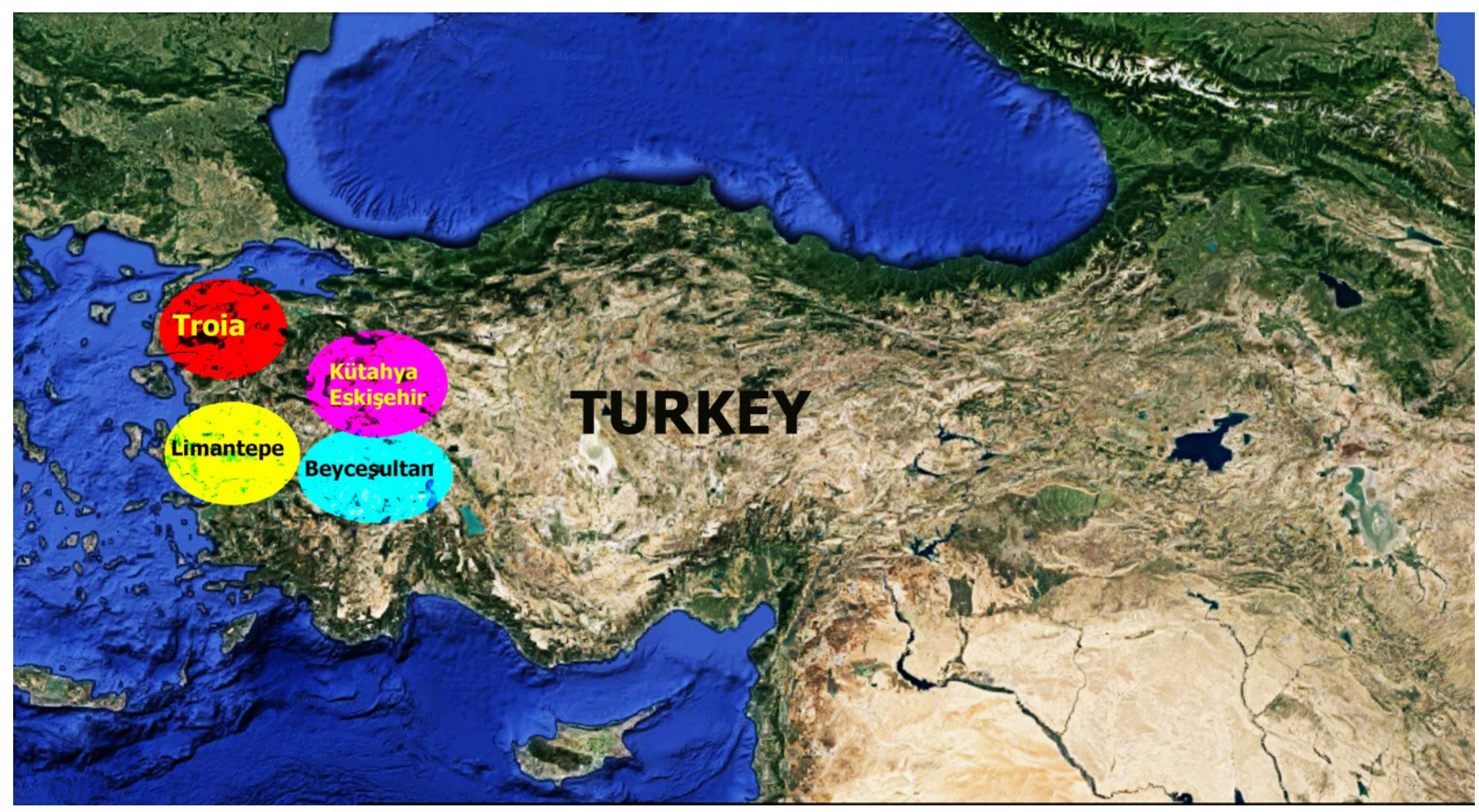

Fig. 2. Map, Important mining districts in western Anatolia in Early Bronze Age.

show that it was made of an iron mine ${ }^{129}$.

The gold, silver, electrum, iron and bronze finds recovered in the tombs of Corum-Alacahöyük are important artifacts showing the extent of the development of mining in Anatolia during the Early Bronze Age ${ }^{130}$. In KamanKalehöyük in Central Anatolia, objects made of iron from the Early Bronze Age and the Middle Bronze Age were found ${ }^{131}$.

\section{CONCLUSION}

During the Early Bronze Age (3000 BC) there is a great improvement in mining and metal processing techniques. In this period, mines are removed from the underground gallery as well as the mines on the surface of the earth. During the Early Bronze Age, mining activities are systematically carried out. In this period, specialization in mining was provided and new techniques were used. In addition to the processing of the metals by hand, production in the mold will become widespread. During the Early Bronze Age there is no mass production in metal processing. Western Anatolian mining, which developed in the Early Bronze Age I (3000-2700 BC), followed a process that reached to the higher point in the Early Bronze Age II (2700-2400 BC). Early Bronze Age II is the period of development of the mining industry and casting techniques. This development continued in the Early Bronze Age III (2400-2000 BC).

Western Anatolia is a region rich in mineral resources. There are rich gold, silver, copper, lead, zinc, iron deposits in Troas Region in western Anatolia. There are rich gold mineral deposits around İzmir-Uşak and rich silver deposits around Kütahya. Western Anatolia settlements during the Early Bronze Age must have provided the needed metals from

\footnotetext{
129 PERNICKA 2001, 371.

130 KOŞAY 1937, 534-542; KAPTAN 1990.

131 AKANUMA 2008, 313.
}

these sources in the surrounding area. Other metals in need should be brought to Western Anatolia by trade from other regions. In both cases, a region with a large number of metal works, such as Western Anatolia, is specialized in mining and has an advanced structure.

Early Bronze Age II shows an increase in the number of settlements in Western Anatolia. As a result, the population of the region also increased. In this period, the need for metal has increased. During the Early Bronze Age there is a large increase in the number of metal works in Western Anatolia and the quality of the works being processed. During the Early Bronze Age, metal production and use and trade increased due to mining activities.

In the Early Bronze Age, metal objects and finds in western Anatolia as well as mining molds, blowers, copper slags, pots, mine preparation, crushing and crushing tools in archaeological centers are important to show the presence of mining workshops in Western Anatolia. In the Early Bronze Age, like Alacahöyük in Central Anatolia, Troia is a center where mining has developed very much in Western Anatolia. The rich gold, silver, bronze and copper objects found in the Troia excavations are important for showing the development of mining in the Early Bronze Age. In Western Anatolia, as well as Troia, centers such as Limentepe and Beycesultan should be seen as important mining centers in their respective regions. For this reason, Troas Region (Troia), İzmir Region (Limantepe) and Inner West Anatolia Region (Beycesultan) are the main centers of mining in Western Anatolia (Fig. 2).

There is an increase in the number of jewelery, ornaments, figurines, pins, axes, knives, daggers, chisels, various weapons and artifacts produced in these centers. In addition to other metals, there is an increase in number 
and variety, especially in bronze-produced objects. The widespread use of arsenic copper in some regions should be due to the low availability of tin in Anatolia. During the Early Bronze Age, both the number of metal works and the variety of works, as well as the quality and the quality, are increasing. In the Early Bronze Age, in addition to the large number of metal finds found in settlements in Western Anatolia, it is important to reveal a large number of metal objets in the Early Bronze Age graves in order to show the prevalence of the metal in the region.

As a result of ongoing investigations and archaeological excavations, a large number of new finds of mining are emerging. As a result of the increase in research, some unclear points will be illuminated in the future.

\section{REFERENCES}

\section{ADRIAENS/YENER/ADAMS 1999}

Adriaens, A./Yener, K. A./Adams, F., An Analytical Study Using Electron and Ion Microscopy of Thin-Walled Crucibles from Göltepe, Turkey, Journal of Archaeological Science 26, 1069-1073.

AKANUMA 2008

Akanuma, H., The Significance of Early Bronze Age Iron Objects from Kaman-Kalehöyük, Turkey, AAS XVII, 313-320. AKISKA/ÜNLÜ/SAYILI 2008

Akıska, S./Ünlü, T./Sayıll, İ. S., Mining Geology of the Gold Occurrences Related to the Arsenopyrites of İzmir-Ödemiş Region, Bulletin of The Mineral Research and Exploration 136, 1-16.

AKDENIZ 2009

Akdeniz, E., New Observations about Yortan Cemetery, Turkish Academiy of Sciences Journal of Archaeology 12, 49-64. APAKIDZE 2008

Apakidze, J., New Excavations at Troia, Bulletin of the BEAR 1963 Georgian National Academy of Sciences, Vol. 2, No. 2, 118-126.

Bear, L. M., The Mineral Resources and Mining Industry of Cyprus, Nicosia (Ministry of Commerce and Industry, Geological Survey Department, Bulletin No. 1).

BEGEMANN/PERNICKA/SCHMITT STRECKER 1994

Begemann, F./Pernicka, E./Schmitt Strecker, S., 1994 Metal Finds from Ilipinar and the Advent of Arsenical Copper, Anatolica 20, 203-209.

BEGEMANN/SCHMITT STRECKER/PERNICKA 2003

Begemann, F./Schmitt Strecker, S./Pernicka, E., On the Composition and Provenance of Metal Finds from Beşiktepe (Troia), In: Wagner, G. A./Pernicka, E./Uerpmann, H. P. (ed.), Troian and the Troad Scientific Approaches (Berlin: Springer), 173-202.

BİLGİ 1997

Bilgi, Ö., Trade in Anatolia During the Pre-Classical Period, PALMET I, 1-57.

BİLGİ/ÖZBAL/YALÇIN 2004

Bilgi, Ö./Özbal, H./Yalçan, Ü., Castings of Copper-Bronze, In: Bilgi, Ö. (ed.), Anatolia Cradle of Castings (İstanbul: Döktas), 1-44.

BOSTANCI 2006

Bostanc1, O., Altın Tepe Höyüğü Yüzey Araştırmaları, In: Avunç, B. (ed.), Studies in Honor of Hayat Erkanal, Cultural Reflections (İstanbul: Homer Kitabevi), 162-169.

BRANIGAN 1974

Branigan, K., Aegean Metalwork of The Early and Middle Bronze Age (Oxford: Clarendon Press).

CIERNY/WEISBERGER 2003

Cierny, J./Weisberger, G., Bronze Age Tin Mines in Central
Asia, In: Mair, A. G./LoSchiavo, F. (ed.), The Problem of Early Tin, BAR International Series 1199 (Oxford: Archaeopress), 23-34.

\section{ÇAĞATAY/ALTUN/ARMAN 1979}

Çağatay, A./Altun, Y./Arman, B., Mineralogy of the Madenbelenitepe (Soğukpınar-Bursa) Tin Mineralization, Bulletin of The Mineral Research and Exploration, No. 92, 2534.

\section{ÇAMBEL/BRAİDWOOD 1970}

Çambel, H./Braidwood, R. J., An Early Farming Village in Turkey, Scientific American 222/3, 50-56.

\section{DAYTON 1971}

Dayton, J. E., The Problem of Tin in the Ancient World, World Archaeology 3, 49-70.

\section{DE JESUS 1972}

De Jesus, P. S., Prehistoric Metallurgy-Another Look, Anatolia XVI, 129-140.

\section{DE JESUS 1978}

De Jesus, P. S., Metal Resources in Ancient Anatolia, Anatolian Studies 28, 97-102.

DE JESUS 1980

De Jesus, P. S., The Development of Prehistoric Mining and Metallurgy in Anatolia, BAR International Series 74 (Oxford: Archaeopress).

DE JESUS/DARDENIZ 2015

De Jesus, P./Dardeniz, G., Archaeological and Geological Concepts on the Topic of Ancient Mining, Bulletin of the Mineral Research and Exploration 151, 231-246.

DE RYCK/ADRİAENS/ADAMS 2005

De Ryck, I./Adriaens, A./Adams, F., An Overview of Mesopotamian Bronze Metallurgy During the 3rd Millennium BC, Journal of Cultural Heritage 6, 261-268.

\section{DURU 1972}

Duru, R., Anadolu'da Bulunmuş Altın Kulak Tıkaçları, Belleten 36/142, 123-136.

\section{DURU 1995}

Duru, R., Bademağacı Kazıları 1993, Kazı Sonuçları Toplantisı XVI-I, 69-77.

EARL/H. ÖZBAL 1996

Earl, B./Özbal, H., Early Bronze Age Tin Processing at Kestel/Göltepe, Anatolia, Archaeometry 38-2, 289-303.

\section{EATON/MCKERRELL 1976}

Eaton, E. R./McKerrell, H., Near Eastern Alloying and Some Textual Evidence for the Early Use of Arsenical Copper, World Archaeology 8/2, 169-191.

EFE 2006

Efe, T., A Trinket Mold from Küllüoba Near Seyitgazi/ Eskişehir, In: Avunç, B. (ed.), Studies in Honor of Hayat Erkanal, Cultural Reflections (İstanbul: Homer Kitabevi), 301-304.

\section{EFE/AY EFE 2001}

Efe, T./Ay Efe, D. Ş. M., Küllüoba: An Early Bronze Age Settlement in North-West Anatolian Hinterland An Overview on the Archaeological Work Done Between Years 1996-2000, Turkish Academiy of Sciences Journal of Archaeology 4, 43-78.

EFE/FIDAN 2006

Efe, T./Fidan, M. E., Pre-Middle Bronze Age Metal Objects from Inland Western Anatolia: A Typological and

\section{EMRE 1971} Chronological Evaluation, Anatolia Antiqua XIV, 15-43.

Emre, K., Anatolian Lead Figürines and Their Stone Moulds, Türk Tarih Kurumu (Ankara).

ERKANAL 2008A

Erkanal, H., Die Neue Forschungen in Bakla Tepe bei İzmir, In: Erkanal, H./Hauptmann, H./Şahoğlu, V./Tuncel, R. (ed.), 
Proceedings of the International Symposium. The Aegean in the Neolithic, Chalcolithic and the Early Bronze Age, October 13th19th 1997, Urla-İzmir (Turkey) (Ankara: Ankara University Press), 165-177.

\section{ERKANAL 2008B}

Erkanal, H., Liman Tepe: A New Light on the Prehistoric Aegean Cultures, In: Erkanal, H./Hauptmann, H./ Şahoğlu, V./Tuncel, R. (ed.), Proceedings of the International Symposium. The Aegean in the Neolithic, Chalcolithic and the Early Bronze Age, October 13th-19th 1997, Urla-İzmir (Turkey), (Ankara: Ankara University Press), 179-190.

ERKANAL/ARTZY/KOUKA 2003

Erkanal, H./Artzy, M./Kouka, O., 2001 Yll Liman Tepe Kazıları, Kazı Sonuçları Toplantısı 24-1, 423-436.

ESIN 1969

Esin, U., Kuantitatif Spektral Analiz Yardimiyla Anadolu'da Başlangıcından Asur Kolonileri Çağına Kadar Bakır ve Tunç Madenciliği, İstanbul Üniversitesi Edebiyat Fakültesi Yayınları, No. 1427.

FIDAN 2006

Fidan, M. E., Waffen aus Metal von Ihren Anfangen bis zum Ende der Frühen Bronzezeit aus dem Inneren Westanatolien, Colloquium Anatolicum V, 91-106.

GALE 2008

Gale, N., Metal Sources for Early Bronze Age Troy and the Aegean, In: Erkanal, H./Hauptmann, H./Şahoğlu, V./ Tuncel, R. (ed.), Proceedings of the International Symposium. The Aegean in the Neolithic, Chalcolithic and the Early Bronze Age, October 13th-19th 1997, Urla-İzmir (Turkey) (Ankara: Ankara University Press), 203-222.

GALE/STOS GALE 2004

Gale, N. H./Stos Gale, Z. A., Changing Patterns in Metallurgy, A Colloquium on the Prehistory of the Cyclades, Cambridge, 25th-28th March 2004, Mcdonald Institute Monograph Series (Cambridge).

GALE/STOS GALE/GILMORE 1985

Gale, N. H./Stos Gale, Z. A./Gilmore, G. R., Alloy Tipes and Copper Sources of Anatolian Copper Alloy Artifacts, Anatolian Studies 35, 143-173.

GENÇER 2006

Gençer, N., Sarımeşe Tepe Madeni Buluntuları, In: Avunç, B. (ed.), Studies in Honor of Hayat Erkanal, Cultural Reflections (İstanbul: Homer Kitabevi), 373-378.

GERRİTSEN/ÖZBAL 2009

Gerritsen, F./Özbal, R., Barcın Höyük Excavations, 2007,

GİLLİS 1991 Kazı Sonuçları Toplantısı 30/3, 457-464.

Gillis, C., Tin in the Aegean Bronze Age, Hydra 10, 1-30.

GÜRKAN/SEEHER 1991

Gürkan, G./Seeher, J., Die Frühbronzezeitliche Nekropole von Küçükhöyük bei Bozüyük, Istanbuler Mitteilungen 41, 39-96.

HAMİLTON 1996

Hamilton, N., Figürines, Clay, Balls, Small Finds and Burials, In: Hodder, I. (ed.), On The Surface: Çatalhöyük 1993-95 (London BIAA \& McDonald Institute), 215-263.

HELWING 2009

Helwing, B., Rethinking the Tin Mountains: Patterns of Usage and Circulation of Tin in Greater Iran from the 4th to the 1st Millennium BC, Turkish Academiy of Sciences Journal of Archaeology 12, 209-219.

HÜRYILMAZ 2008

Hüryılmaz, H., Town Fact and Sociocultural Life in Gökçeada-Yenibademli Höyük, In: Erkanal-Öktü, A./Günel, S./Deniz, U. (ed.), Batı Anadolu ve Doğu Akdeniz Geç Tunç Çağı Kültürleri Üzerine Yeni Araştırmalar (Ankara), 141-150.

\section{JONES 2007}

Jones, M. R., Oxhide Ingots, Copper Production, and The Mediterranean Trade in Copper and Other Metals in the Bronze Age, Master of Arts Thesis, Texas A\&M University, May 2007.

\section{KAPTAN 1980}

Kaptan, E., New Findings on the Mining History of Turkey Around Tokat Region, Bulletin of The Mineral Research and Exploration 93-94, 65-76.

KAPTAN 1981

Kaptan, E., The Significance of Tin in Turkish Mining History and Its Origin, Bulletin of The Mineral Research and Exploration 95-96, 106-114.

\section{KAPTAN 1982}

Kaptan, E., New Discoveries in the Mining History of Turkey in the Neighborhood of Gümüşköy, Kütahya, Bulletin of The Mineral Research and Exploration 97/98, 59-67.

\section{KAPTAN 1990}

Kaptan, E., Findings Related to the History of Mining in Turkey, Bulletin of The Mineral Research and Exploration 111, 75-84.

KAPTAN 1995A

Kaptan, E., Tin and Ancient Tin Mining in Turkey, Anatolica 21, 197-203

\section{KAPTAN 1995B}

Kaptan, E., Anadolu'da Eski Madencilik, In: Erkanal, A./ Erkanal, H./Hüryllmaz, H./Ökse, A. T./Çınardalı, N./Günel, S./Tekin, H./Uysal, B./Yalcıklı D. (ed.), Memoriam İ. Metin Akyurt-Bahattin Devam Ant Kitabl/Studies for Ancient Near Eastern Cultures (İstanbul), 189-195.

\section{KAPTAN 2006}

Kaptan, E., Anadolu'da Eski Dönemlere Ait Cevher Hazırlama Aletlerinden Seçilmiş Örnekler, In: Avunç, B. (ed.), Studies in Honor of Hayat Erkanal, Cultural Reflections (İstanbul: Homer Kitabevi), 467-472.

\section{KAPTAN 2008}

Kaptan, E., Metallurgical Residues from Late Chalcolithic and Early Bronze Age Liman Tepe, In: Erkanal, H./ Hauptmann, H./Şahoğlu, V./Tuncel, R. (ed.), Proceedings of the International Symposium. The Aegean in the Neolithic, Chalcolithic and the Early Bronze Age, October 13th-19th 1997, Urla-İzmir (Turkey) (Ankara: Ankara University Press), 243-250.

\section{KARTALKANAT 2008}

Kartalkanat, A., History of Mining in Anatolia: The Mining Activities in Kütahya - Gümüşköy since 3500 Years, Bulletin of The Mineral Research and Exploration 137, 91-97.

KASSİANIDOU/KNAPP 2005

Kassianidou, V./Knapp, A. B., Archaeometallurgy in the Mediterranean: The Social Context of Mining, Technology, and Trade, In: Blake, E./Knapp, A. B. (ed.), The Archaeology of Mediterranean Prehistory (Oxford: Blackwell Publishing), 215-251.

\section{KLENGEL 2009}

Klengel, H., Altassyrischer Zinnhandel mit Anatolien, Turkish Academiy of Sciences Journal of Archaeology 12, 175182.

\section{KOLANKAYA BOSTANCI 2008}

Kolankaya-Bostanc1, N., The Technological and Typological Analysis of the Chipped Stone Artefacts from Panaztepe Excavations, In: Erkanal-Öktü, A./Günel, S./Deniz, U. (ed.), Batı Anadolu ve Doğu Akdeniz Geç Tunç Çağl Kültürleri Üzerine Yeni Araştırmalar (Ankara: Hacettepe Üniversitesi), 167-177.

\section{KORFMANN 1986}

Korfmann, M., Beşik-Yassıtepe ve Beşik-Mezarlığı 1985 Ön 
Raporu, Kazı Sonuçları Toplantısı VIII-I, 263-271.

KORFMANN 1997

Korfmann, M., Troia-Ausgrabungen 1996, Studia Troica 7, 1-72.

\section{KORFMANN 2003A}

Korfmann, M., Troia in Light of New Research, Universitat Trier, Keynote Lecture, 12 November 2003. 1-71.

KORFMANN 2003B

Korfmann, M., Die Arbeiten in Troia/Wilusa 2002/2002 Work at Troia/Wilusa, Studia Troica 13, 3-26.

KOŞAY 1937

Koşay, H. Z., The Results of the Excavations Made on Behalf of the Turkish Historical Society at Alaca Höyük in the Summer of 1936, Belleten 1/2, 534-542.

KOVENKO 1940

Kovenko, V., Balya Lead Mines (Turkey), Bulletin of The Mineral Research and Exploration 21, 587-593.

LAFFINEUR 2008

Laffineur, R., Aspects of Early Bronze Age Jewellery in the Aegean, In: Erkanal, H./Hauptmann, H./Şahoğlu, V./ Tuncel, R. (ed.), Proceedings of the International Symposium. The Aegean in the Neolithic, Chalcolithic and the Early Bronze Age, October 13th-19th 1997, Urla-İzmir (Turkey) (Ankara: Ankara University Press), 323-332.

LAMB 1937

Lamb, W., Excavations at Kusura Near Afyon Karahisar, Archaeologia 86 (Oxford), 1-64.

LAUGHLIN/TODD 2000

Laughlin, G. J./Todd, J. A., Evidence for Early Bronze Age Tin Ore Processing, Materials Characterization 45, 269-273.

LEHNER/YENER/BURTON 2009

Lehner, J. W./Yener, A./Burton, J., Lead Isotope Analysis and Chemical Characterization of Metallic Residues of an Early Bronze Age Crucible from Göltepe: Using ICP-MS, Turkish Academiy of Sciences Journal of Archaeology 12, 165174.

\section{LENGERANLI 2008}

Lengeranll, Y., Metallic Mineral Deposits and Occurences of the İzmir District, In: Erkanal, H./Hauptmann, H./ Şahoğlu, V./Tuncel, R. (ed.), Proceedings of the International Symposium. The Aegean in the Neolithic, Chalcolithic and the Early Bronze Age, October 13th-19th 1997, Urla-İzmir (Turkey) (Ankara: Ankara University Press), 355-398.

\section{LLOYD/MELLAART 1962}

Lloyd, S./Mellaart, J., Beycesultan I: The Chalcolithic and Early Bronze Age Levels (London: The British Institute of Archaeology at Ankara).

\section{MADDİN/WHEELER/MUHLY 1977}

Maddin, R./Wheeler, T. S./Muhly, J. D., Tin in the Ancient Near East: Old Questions and New Finds, Expedition 19-2, 35-47.

MELLAART 1964

Mellaart, J., Excavations at Çatal Hüyük, Anatolian Studies $14,39-119$

MERİÇ 1993

Meriç, R., 1991 Yılı Alaşehir Kazısı, Kazı Sonuçları Toplantısı XIV-II, 355-363.

MUHLY 1985

Muhly, J. D., Sources of Tin and the Beginnings of Bronze Age Metallurgy, American Journal of Archaeology 89, 275291.

\section{MUHLY 1988}

Muhly, J. D., The Beginnings of Metallurgy in the Old World, In: Maddin, R. (ed.), The Beginning of the Use of Metals and Alloys (Cambridge: MIT Press), 2-20.

MUHLY 1993
Muhly, J. D., Early Bronze Age Tin and the Taurus, American Journal of Archaeology 97, 239-253.

MUHLY 1999

Muhly, J. D., Copper and Bronze in Cyprus and the Eastern Mediterranean, In: Piggot, V. C. (ed.), Archaeometallurgy of the Asian Old World, MASCA Research Papers in Science and Archaeology, Vol. 16, The University Museum, University of Pennsylvania, 15-25.

MUHLY/PERNICKA 1992

Muhly, J. D./Pernicka, E., Early Trojan Metallurgy and the Metals Trade, In: Hermann, J. (ed.), Heinrich Schliemann: Grundlagen und Ergebnisse Moderner Archaologie 100 Jahre nach Schliemann's Tod (Berlin: Akademie Verlag), 309-318.

MUHLY/WERTIMME 1973

Muhly, J. D./Wertime, J. A., Evidence for the Sources and Use of Tin During the Bronze Age of the Near East: A Reply to J. E. Dayton, World Archaeology 5, 111-122.

MUHLY/MADDİN/STECH/ÖZGEN 1985

Muhly, J. D./Maddin, R./Stech, T./Özgen, E., Iron in Anatolia and the Nature of the Hittite Iron Industry, Anatolian Studies 35, 67-84.

MÜLER KARPE 1994

Müler Karpe, A., Altanatolisches Metallhandwerk, (Neumünster: Wachholtz).

NİKOLOVA 2005

Nikolova, L., Social Changes and Cultural Interactions in Later Balkan Prehistory Later Fifth and Fourth Millennia cal BCE, In: Fritz, J./Higgins, J. (ed.), Prehistoric Archaeology\& Anthropological Theory and Education, RPRP 6-7, 87-96.

\section{NIKOLOVA 2008}

Nikolova, L., Balkan- Anatolian Cultural Horizons from the Fourth Millennium BC and Their Relations to the Baden Cultural Complex, In: Furholt, M./Szmyt, M./Zastavny, A. (ed.), The Baden Complex and the Outside World. Proceeding of the 12th Annual Meetingof the EAA in Cracow 19-24th September 2006, Studien zur Archaologie in Ostmittleuropa. Band 4 (Bonn: Rudolf Habelt), 157- 166.

ÖZBAL 2009

Özbal, H., New Analytical Data from Göltepe Crucibles, Turkish Academiy of Sciences Journal of Archaeology 12, 155163.

ÖZSAİT 2000

Özsait, M., 1998 Yılı Harmanören (Göndürle Höyük) Kazısı, Kazı Sonuçları Toplantısı 21-1, 371-380.

ÖZTÜRK/HANİLÇİ 2009

Öztürk, H./Hanilçi, N., Metallogenic Evaluation of Turkey: Implacations for Tin Sources of Bronze Age in Anatolia, Turkish Academiy of Sciences Journal of Archaeology 12, 105116.

PERNICKA 2001

Pernicka, E., Metaller Yeni Bir Çı̆̆ır Açıyor. Tunç, Demir ve Gümüş, In: Düş ve Gerçek Troia (İstanbul: Homer Kitabevi), 369-372.

PERNİCKA/EIBNER/ÖZTUNALI/WAGNER 2003

Pernicka, E./Eibner, C./Öztunalı, Ö./Wagner, G. A., Early Bronze Age Metallurgy in the Northeast Aegean, In: Wagner, G. A./Pernicka, E./Uerpmann, H. P. (ed.), Troian and the Troad Scientific Approaches (Berlin: Springer), 143172.

PİGOTT 1982

Pigott, V. C., The Innovation of Iron Cultural Dynamics in Technological Change, Expedition 25, 20-25.

\section{PİGOTT 1999}

Pigott, V. C., The Archaeometallurgy of the Asian Old World: Introductory Comments, In: Pigott, V. C. (ed.), Archaeometallurgy of the Asian Old World, MASCA Research 
Papers in Science and Archaeology, Vol. 16, 1-13.

PULAK 2009

Pulak, C., The Uluburun Tin Ingots and the Shipment of Tin by Sea in the Late Bronze Age Mediterranean, Turkish Academiy of Sciences Journal of Archaeology 12, 189-208.

SAZCI/TREISTER 2006

Sazc1, G./Treister, M., Troias Gold-Die Schatze des Dritten Jahrtausends vor Christus, Manfred O. Korfmann (Hrsg.). Troia Archaologie eines Siedlungshügels und seiner Landschaft (Mainz am Rhein: Philipp von Zabern), 209-218.

SEEHER 2000

Seeher, J., Die Bronzezeitliche Nekropole von DemircihüyükSarlket. Ausgrabungen des Deuthschen Archaologischen Instituts In Zusammenarbeit mit dem Museum Bursa, 19901991 (Tübingen: Ernst Wasmuth Verlag).

SEEHER/KAUDER 1996

Seeher, A. B./Kauder, J. O., Demircihüyük IV, Die Kleinfunde (Mainz am Rhein).

SHEPHERED 1993

Shephered, R., Ancient Mining (London / New York: Published for the Institution of Mining and Metallurgy by Elsevier Applied Science).

SOYKAN/MUTLUER 1995

Soykan, F./Mutluer, M., The Geographical Repartition of Mining and Mineral Deposits in Türkiye, Aegean Geographical Journal 8, 37-56.

STECH/PIGGOTT 1986

Stech, T./Piggott, V., The Metals Trade in Southwest Asia in the Third Millennium B.C., Iraq 48, 39-64.

STOS GALE/GALE 1990

Stos Gale, Z. A./Gale, N. H., The Role of Thera in the Bronze Age Trade in Metals, Thera and the Aegean World III, 72-91.

STOS GALE/GALE 1990

Stos Gale, Z. A./Gale, N. H., Lead Isotopic and Other Isotopic Research in the Aegean, Aegaeum 24, 83-101.

STOS GALE/GALE 1990

Stos Gale, Z. A./Gale, N. H., Bronze Age metal artefacts found on Cyprus- metal from Anatolia and the Western Mediterranean, Trabajos De Prehistoria 67, 2, juliodiciembre 2010, 389-403.

STOS GALE/MACDONALD 1991

Stos Gale, Z. A./Macdonald, C. F., Sources of Metals and Trade in the Bronze Age Aegean, Studies in Mediterranean Archaeology XC, 249-288.

STRABO

Strabo, Geography, Loeb Classical Library.

STRONACH 1959

Stronach, D., An Early Metal Hoard from Beycesultan, Anatolian Studies 9, 47-50.

ŞAHOĞLU 2005

Sahoğlu, V., The Anatolian Trade Network and the Izmir Region During the Early Bronze Age, Oxford Journal of Archaeology 24 (4), 339-361.

ŞENER 2003

Şener, A. K., Preliminary Study of the Low-Sulphidation Epithermal Ovacık Gold-Silver Deposit, Western Turkey, In: Eliopoulos (ed.), Mineral Exploration and Sustainable Development (Rotterdam: Millpress), 519-522.

\section{TREİSTER 1996}

Treister, M., The Trojan Treasures: Description, Chronology, Historical Context, In: Tolstikov, V./Treister, M. (ed.), The Gold of Troy (New York: Abrams), 197-234.

WAGNER et alii 1984

Wagner, G. A./Pernicka, E./Seeliger, T. C./Öztunall, Ö./ Baranyi, I./Begemann, F./Schmitt-Strecker, S., Geologische Untersuchungen zur Frühen Metallurgie in NW-Anatolien/
Geological Investigation on the Early-Metallurgie in NWAnatolia, Bulletin of The Mineral Research and Exploration 101-102, 45-81.

WARNER 1994

Warner, J. L., Elmalı-Karataş II, The Early Bronze Age Village of Karatas (Bryn Mawr: Dept. of Classical and Near Eastern Archaeology, Thomas Library, Bryn Mawr College).

WHEELER/MADDİN/MUHLY 1975

Wheeler, T. S./Maddin, R./Muhly, J. D., Ingots and the Bronze Age Copper Trade in the Mediterranean: A Progress Report, Expedition, Summer 1975, 31-39.

WİLLIES 1990

Willies, L., An Early Bronze Age Tin Mine in Anatoliai, Bulletin of the Peak District Mines Historical Society, Vol. 11, No. 2, 91-96.

WİLLIES 1992A

Willies, L., Reply to Pernicka et al.: Comment on the Discussion of Ancient Tin Sources in Anatolia, Journal of Mediterranean Archaeology 5 (1), 99-103.

\section{WİLLİES 1992B}

Willies, L., Report on the 1991 Archaeological Survey of Kestel Tin Mine, Turkey, Bulletin of the Peak District Mines Historical Society, Vol. 11, No. 5, 241-247.

WİLLİES 1995

Willies, L., Kestel Tin Mine, Turkey. Interim Report 1995, Bulletin of the Peak District Mines Historical Society, Vol. 12, No. 5, 1-11.

WRİGHT 1998

Wright, J. C., The Place of Troy Among the Civilizations of the Bronze Age, Classical World 91, 356-368.

YAKAR 1984

Yakar, J., Regional and Local Schools of Metalwork in Early Bronze Age Anatolia, Anatolian Studies 34, 59-86.

YAKAR 1985

Yakar, J., The Later Prehistory of Anatolia. The Late Chalcolithic and Early Bronze Age, Part I-II, BAR İnternational Series 268 (Oxford: Archaeopress).

YALÇIN 2003

Yalçın, Ü., Entwicklung der Metallurgie in Anatolien, In: Özdoğan, M./Hauptmann, H./Başgelen, N. (ed.), Studies Presented to Ufuk Esin. From Village to Cities Early Villages in the Near East. 2 (İstanbul: Arkeoloji ve Sanat yayınları), 533-545.

YALÇIN 2008

Yalçın, Ü., Ancient Metallurgy in Anatolia, In: Yalçın, Ü./ Özbal, H./Paşamehmetoğlu, A. G. (ed.), International Conference AMITEM 2008 Ancient Mining in Turkey and The Eastern Mediterranean, June 15-22, 2008 (Ankara: Atılım Univ.), 15-40.

YALÇIN 2009

Yalçın, Ü., A Strategically Important Metal: Tin, Turkish Academiy of Sciences Journal of Archaeology 12, 99-103.

YALÇIN/ÖZBAL 2009

Yalçın, Ü./Özbal, H., Ein Neues Zinnvorkommen in Kayseri-Hisarcık, Zentralanatolien: Ein Vorbericht, Turkish Academiy of Sciences Journal of Archaeology 12, 117-122.

YAYLALI/AKDENIZ 2002

Yaylalı, S./Akdeniz, E., Aphrodisias Müzesi'ndeki Karahisar Buluntuları, OLBA VI, 1-40.

YENER 1995

Yener, K. A., Göltepe 1993 Kazı Sonuçları, Kazı Sonuçları Toplantist 16-1, 177-188.

YENER 2000

Yener, K. A., The Domectication of Metals: The Rise of Complex YENER 2008 
Yener, K. A., Revisiting Kestel Mine and Göltepe: The Dynamics of Local Provisioning of Tin During the Early Bronze Age, In: Yalçın, Ü./Özbal, H./Paşamehmetoğlu, A. G. (ed.), International Conference AMITEM 2008 Ancient Mining in Turkey and The Eastern Mediterranean, June 15-22, 2008 (Ankara: Atılım Univ.), 57-64.

YENER 2009

Yener, K. A., Strategic Industries and Tin in the Ancient Near East: Anatolia Updated, Turkish Academiy of Sciences Journal of Archaeology 12, 143-154.

\section{YENER/GOODWAY 1992}

Yener, K. A./Goodway, M., Response to Mark E. Hall and Sharon R. Steadman ' Tin and Anatolia: Another Look, Journal of Mediterranean Archaeology 5 (1), 77-90.

YENER/VANDIVER 1993A

Yener, K. A./Vandiver, P. B., Tin Processing at Göltepe, an Early Bronze Age Site in Anatolia, American Journal of Archaeology 97, 207-238.

YENER/VANDIVER 1993B

Yener, K. A./Vandiver, P. B., Reply to J. D. Muhly, Early Bronze Age Tin and the Taurus, American Journal of Archaeology 97, 255-264.

\section{YENER et alii 1989}

Yener, K. A./Özbal, H./Kaptan, E./Pehlivan, A. N./Goodway, M., Kestel: An Early Bronze Age Source of Tin Ore in the Taurus Mountains, Turkey, Science, Vol. 244, 200-203.

YENER et alii 1991

Yener, K. A./Sayre, E. V./Joel, E. C./Özbal, H./Barnes, I. L./Brill, R. H., Stable Lead Isotope Studies of Central Taurus Ore Sources and Related Artifacts from Eastern Mediterranean Chalcolithic and Bronze Age Sites, Journal of Archaeological Science, Vol. 18/5, 541-577.

YENER/ANDRIAENS/EARL/ÖZBAL 2003

Yener, K. A./Andriaens, A./Earl, B./Özbal, H., Analyses of Metalliferous Residues, Crucible Fragments, Experimental Smelts and Ores from Kestel Tin Mine and the Tin Processing Site of Göltepe, Turkey, In: Craddock, P. T./Lang, J. (ed.), In Mining and Metal Production Through the Ages (London: The British Museum Press), 181-197.

\section{YOUNG 1972}

Young, W. J., The Fabulous Gold of the Pactolus Valley, Boston Museum Bulletin 70, 5-13. 